\title{
GLOBALISATION OF THE UKRAINIAN LANGUAGE LEXICAL SYSTEM: AGE, GENDER AND EDUCATIONAL DIMENSIONS
}

\author{
Oleh Semeniuk \\ Volodymyr Vynnychenko Central Ukrainian State Pedagogical University, Kropyvnytskyi, Ukraine \\ semenyuk_oleg@ukr.net \\ Tetyana Leleka \\ Volodymyr Vynnychenko Central Ukrainian State Pedagogical University, Kropyvnytskyi, Ukraine \\ tleleka@ukr.net
}

\author{
Olena Moskalenko \\ National Aviation University, Kyiv, Ukraine \\ concordmoskalenko@ukr.net
}

\begin{abstract}
The article is aimed at the analysis of a linguistic problem of the use of Anglo-American loanwords in the Ukrainian language connected with the English globalisation and transformation into the language of international communication. The authors argue that the Anglo-Americanisms can be transferable to the original Ukrainian synonymous words because there are analogues and oneword equivalents for them. The youth slang is considered as a separate part of the national language, which represents the development of society. Therefore, the authors make an attempt to identify its role in globalisation processes. The hypothesis of the research is that the use of Anglo-Americanisms depends on the age, gender and educational dimensions. The analysis of linguistic behaviour based on empirical data was carried out. In order to achieve the aim of the research, a set of scientific methods was used, namely: analysis, synthesis, comparing, generalisation, questioning and interviewing. The study involved 300 people, 150 women and 150 men. Gender has a certain influence on the degree of the use of Anglo-Americanisms in the speech of youth: young men use English loans more often than young women. The participants were divided into two age groups of 17-18 years old and 19-20 years old. The difference between two groups is not significant. Participants were also subdivided into two groups depending on the factor where they received their education. One group consisted of the students studying in higher educational institutions, and the second one was made up of students from colleges and technical schools. The loanwords are typical of the speech of all the young people regardless of their speciality. The youth slang affects the use of English loanwords in the Ukrainian language. The majority of respondents (64\%) showed the increasing number of Anglo-Americanisms in their vocabulary. Most of young people prefer them to the Ukrainian equivalents. The Ukrainian youth slang is full of Anglo-Americanisms and this process is getting more intense.
\end{abstract}

Keywords: Anglo-Americanism; loanword; globalisation; internationalisation; slang; language contact.

\section{Introduction}

The problem of using foreign words in the language, as well as the possibility of replacing them with their original names is vital in the society where socioeconomic transformations are taking place. The processes of globalisation are reflected in the change of lexical composition of the Ukrainian language, as the new forms of professional relations between people are appearing. Nowadays, the number of loanwords from English, i.e. Anglo-Americanisms, in the Ukrainian language is increasing, so we can observe the Americanisation of the Ukrainian language. In general, it is equivalent to the growing internationalisation.

The changing world reality leads to the changing mission of language and communication. The key features of globalisation are mobility and interconnectedness (Chaoyuan, 2016, p. 320). Mobility of goods, services, and people necessarily involves representations, narratives and discourses (Fairclough, 2007). These aspects lead to the global cultural, political and economic integration.

Linguistic stratigraphy is the systematic investigation of the layering of grammatical and lexical material in a language or dialect, which reflects its historical development and past contacts between its speakers and bearers of other linguistic and cultural traditions (Ross, 2003).Whereas linguists have focused on linguistic traits related to the user's geographical origin (dialect) and sociological traits related to the class or degree of formal education (sociolects), any analysis of an increasingly mediated use of language in a society must also take into account the linguistic variants that arise out of specific media (Hjarvard, 2003, p. 76).

The importance of the proposed study is determined by the general tendency of the humanitarian paradigm of knowledge in a comprehensive study of the actual processes of language contacts. So, it makes up the object of scientific interests of the representatives of a sociolinguistic approach (Hans, 2017). The results of such contacts can be connected with the language globalisation.

The relationship between language and gender has long been of interest within the scope of sociolinguistics and related disciplines. There are differences between females' and mails' speech across

Semeniuk, O., Leleka, T., \& Moskalenko, O. (2020). Globalisation of the Ukrainian language lexical system: age, gender and educational dimensions. Advanced Education, 15, 81-88. DOI: 10.20535/2410-8286.174640 
languages, in many cases identifying distinct female and male language forms. Gender has also been a social variable in quantitative studies of language variations. It has been found out that amongst speakers from similar social backgrounds, women tend to use more standard or prestige language means and structures while men are apt to use more vernacular language means (Sunderland \& Swann, 2015).

Research in educational linguistics is now challenging the efficiency of monolingual approaches that often dominate the educational practices in multilingual settings (Kiramba, 2018, p. 292). Language variation allows the speakers to identify themselves in a multi-dimensional society. Age (social, not chronological) is one of the dimensions on which we construct identities for ourselves. The relation between the ageing process and language use has traditionally been analysed from two points of view: the change of language used during the lifespan of an individual (Cheshire, 2002, p. 429). The age-specific use of language refers to the first approach, with the generation-specific use of language reserved for the latter. This distinction has been an important one in the analysis of language changes.

Youth language practices should be understood as translingual not only due to their varied recombination of linguistic and cultural resources, genres, modes, styles and repertories, but also due to their direct subtextual connections with wider socio-cultural, historical and ideological meanings. Secondly, online users metalinguistically claim authenticity in terms of their own translingual practices as opposed to other colliding language ideologies such as linguistic dystopia. How they relocalise the notion of authenticity, however, differs profoundly depending on their own often diverse criteria, identities, beliefs and ideas (Sender, 2015, p. 439).

Slang is based on literary language or foreign language inclusion. Youth slang is a separate part of the national language, which reflects to a certain extent the level of culture, education, and development of society (Vasylenko, 2001, p. 502). The slang is traditionally opposed to the official common language. In view of the mentioned above, the paper is a study of the language problem within globalisation context with a focus on the tendency of the English language transformation into a single global language of international communication through the standards of education.

The aim of the article is to carry out a comparative study of Anglo-American loanwords in modern Ukrainian youth slang. The object of the research is Anglo-Americanisms in the Ukrainian youth slang due to studying English at school, college, technical school and university. In addition, the social networks, travelling abroad and modern mass media play an extremely important role in forming the speech pattern of Ukrainian youth. Slang can be distorted, abnormal, vulgar speech when the subject is given a humiliating assessment. Youth slang easily absorbs foreign words; the loanwords from Anglo-American sources most often have an internal form that is understandable to the speaker: the speakers of youth sublanguages usually know the content of specific English prototypes from which they form slang. Young people use AngloAmericanisms much more often than representatives of the elder generation. Their speech differs in the variety and frequency of loan words and the proximity of pronunciation of Anglo-Americanisms compared to the original. The process of the appearance of English slang has specific characteristics. Unlike loanwords from a literary language, where the reason for borrowing is the lack of tokens to denote a particular reality, slang often takes lexical elements for the nomination of such concepts that already have a verbal form in the literary language. This indicates the secondary character of the youth slang and its orientation towards the system of literary language (Vasylenko, 2001, p. 510).

The subject of the study is represented by the features of the use of loanwords in the Ukrainian language according to age, gender and educational dimensions. In this work, borrowing is considered as one of the forms of the implementation of language contact as a process of social idea, characterised by language relations. The borrowing process, above all, concerns the use of units of one language in another, which does not violate the integrity of the recipient language and does not always require a situation of bilingualism (Leleka \& Moskalenko, 2018, p. 145).

So that the aim may be successfully attained, the following objectives are stated in the article:

- to define the phenomenon of Anglo-Americanisation as a result of language contacts,

- to determine the role of the loanwords in Ukrainian youth slang,

- to single out the gender, age and educational dimensions of Anglo-Americanisms in modern Ukrainian youth slang,

- to specify the results of language globalisation.

The use of Anglo-Americanisms in the Ukrainian language at the beginning of the 21st century has positive and negative consequences. As a positive effect, we can mention the rapid filling of the terminological gaps of the recipient language, which was determined by globalisation conditions (Azhniuk, 2008, p. 195). 


\section{Methods}

Research design

The analyses of linguistic behaviour must be based on empirical data. By this, we mean data collected through observation, broadly defined, as opposed to data constructed on the basis of introspection. The most commonly studied data among sociolinguists are those representing speakers' performance - the way they actually use language.

Methods for analysing sociolinguistic data are those procedures that sociolinguists use, analysing the source material obtained in the course of research. The varieties of correlation analysis are taken into account to study the relationships between variables, dependent and independent ones.

Questionnaire is one of the widely used tools of the sociolinguistic survey since the direct observation of individual informants and small groups is not always representative enough. Methods for collecting sociolinguistic data include: direct observation, which has recently found a wide application; interviewing; questionnaire; testing; analysis of the data collected by the sociolinguist and documentary sources.

The development of the tasks requires the application of the following methods: comparative method for the study of foreign loanwords in youth slang in terms of gender, age, and educational characteristics; functional one to identify common and specific age, gender, and educational characteristics in the use of the loanwords in the Ukrainian language; quantitative calculation of lexical units for their linguistic analysis.

\section{Participants}

In the survey, respondents were surveyed to characterise a specific sociolinguistic phenomenon. The study involved 300 people, 150 women and 150 men. They were divided into two age groups, namely 17-18 years old and 19-20 years old. Participants were also divided into two groups depending on the factor where they receive their education. One group consisted of students from higher educational institutions, and the second group comprised the students from colleges and technical schools.

\section{Research procedure}

At the preparatory stage, it was necessary for us to introduce subjects into the problem and to find out the possibility of singling out a special, control group. Members of a speech community are aware and make use of the different possibilities that the variability of language offers. In acknowledging the role of variability in language, linguists aim at identifying and accounting for a systematic pattern that governs the occurrence of the variants.

The participants received a list of 30 loanwords from the English language in order to find out how well they know the meaning of the loanwords and how often they use them. They had to characterise each word according to the following criteria: a) the meaning of the borrowing; b) how often they use them (always, often, seldom, never); c) the reason for using the Anglo-Americanisms instead of the Ukrainian words; d) the contamination of the Ukrainian language.

Theoretical significance of the work is to identify the patterns of functions of foreign loans in Ukrainian youth slang under the influence of various factors. Among the analysed Anglo-Americanisms that have duplicate forms in the Ukrainian language there are: nouns: бейбi-baby, герла-girl, дрінк-drink, кемncamp, кеш-cash, кілер-killer, кіс-kiss, лузер-loser, мані-mоnеу, меседж-message, паті-party, піпл-peоple, респект - respect, сабвей - subway, сайз - size, сейшн - session, секьюріті - security, сюрпрайз - surprise, тінейджер-teenager, фешн-fashion, френд-friend, шузи-shoеs, юзер-user; adjectives: екс-ex, кул-cool; verbs: чилитися - to chill; interjections: Bay! - Wow!, copi - sorry, окейokey, Ync! - Oops! (Table 1).

Table 1. Anglo-Americanisms and their Ukrainian equivalents

\begin{tabular}{|c|c|}
\hline Anglo-Americanism & Ukrainian equivalent \\
\hline бейбi-baby & дитина \\
\hline герла-girl & дівчина \\
\hline дрінк-drink & напій \\
\hline кемп-сатр & mабір \\
\hline кеш-cash & готівка \\
\hline кілер-killer & вбивия \\
\hline kic - kiss & поцілунок \\
\hline лузер-loser & невдаха \\
\hline мані-money & гроші \\
\hline меседж-теssage & повідомлення \\
\hline
\end{tabular}




\begin{tabular}{|c|c|}
\hline nami-party & гулянка \\
\hline ninл-people & люди \\
\hline респект-respect & повага \\
\hline сабвей-subway & підземка \\
\hline caйз-size & розмір \\
\hline сейшн-session & вечірка \\
\hline секьюріті-security & охорона \\
\hline сюрпрайз - surprise & сюрприз \\
\hline тінейджер - teenager & підліток \\
\hline фешн-fashion & мода \\
\hline френд - friend & $\partial p y z$ \\
\hline uузи-shoes & туфлі \\
\hline юзер-user & користувач \\
\hline$e \kappa c-\boldsymbol{e x}$ & колищній \\
\hline кул-cool & крутий \\
\hline чилитися - to chill & розслаблятися \\
\hline Bay! -Wow! & $y x !$ \\
\hline copi-sorry & вибач \\
\hline окей-okey & добре \\
\hline Ync! -Oops! & $O \check{u} !$ \\
\hline
\end{tabular}

In this study, a 100-point scale was used to show the percentage of data. To process the information obtained through the field observations, different kinds of correlation analysis are used to study the relationships between dependent and independent variables. For sociolinguistics, there are typical correlations, in which certain social parameters, stratification and situation, act as independent variables while linguistic phenomena function as dependent variables.

The following procedure has been applied: dependencies have been described in the quantitative distribution of options, separately for each social section - age, education, gender, and then commented on the content (sociolinguistic) side; this uses tabular data, dependency graphs, the results of applying some mathematical-statistical criteria.

\section{Results}

Results for the groups of the respondents reported below are arranged by necessary sociolinguistic characteristics. Gathered anonymously survey results that follow reflect the opinions of all the participants. The results and discussion for the survey will be presented according to the research objectives listed above.

The use of Anglo-Americanisms by the students of the universities.

As the study showed, the main sources of the appearance of English words in the speech of young people are the friends $(60 \%)$, television $(20 \%)$, computer games $(10 \%)$, the Internet $(10 \%)$. It should be noted that $80 \%$ of respondents answered that they know the meanings of foreign words, while $20 \%$ did not understand all the words. The main cases when English words are used are for communication in social networks $(50 \%)$ and in the circle of friends $(50 \%)$.

Therefore, according to our research, young people often use Anglo-Americanisms when they speak to each other in spite of the fact that there are Ukrainian words available. From these small surveys, one can conclude that the slang with the use of English words are known to the majority of young people, while more than half of them constantly use fashionable words, but not everyone likes speech filled with AngloAmericanisms. The main source of the vocabulary replenishment is communication with friends.

Identification of these words did not cause any special difficulties: all respondents are familiar with these loans. They either use them in their speech, or hear them in speech of other people from their environment. In our survey, there are two groups of young people: the students of higher educational institutions and the students and graduates of the colleges and technical schools. In the course of our study, we analysed gender and age features of the use of Anglo-Americanisms. Our first data deal with the students of higher educational institutions (Table 2). 
Table 2. The number of the people who know the meaning of Anglo-Americanisms

\begin{tabular}{ccc}
\hline All the words & \multicolumn{1}{c}{ Mere than half } \\
\hline & Age of $17-18, \%$ & \\
\hline 92 & & 10 \\
\hline & Age of $19-20, \%$ & \\
\hline 90 & Women & 9 \\
\hline & Age of $17-18, \%$ & \\
\hline 91 & & 11 \\
\hline
\end{tabular}

The results of the preliminary survey showed that the students majoring in Foreign Languages gave a greater number of affirmative answers to the proposed questions, but we decided not to separate them into a control group during the experiment, since it is important for us to define the degree of assimilation of borrowed units among the students in general, no matter what field they specialise in.

Approximately $75 \%$ of the respondents who use loans perceive Anglo-Americanisms as their friendly words, and only $25 \%$ - as foreign ones. The respondents are well aware of the fact that they use AngloAmericanisms in their slang, referring to the fact that they are actively replenishing the Ukrainian language with new words (Table 3 ).

Table 3. The number of people who use Anglo-Americanisms instead of Ukrainian equivalents

\begin{tabular}{|c|c|c|c|}
\hline Always & Often & Seldom & Never \\
\hline \multicolumn{4}{|c|}{ Men } \\
\hline \multicolumn{4}{|c|}{ Age of $17-18, \%$} \\
\hline 27 & 35 & 33 & 5 \\
\hline \multicolumn{4}{|c|}{ Age of $19-20, \%$} \\
\hline 19 & 30 & 59 & 10 \\
\hline \multicolumn{4}{|c|}{ Women } \\
\hline \multicolumn{4}{|c|}{ Age of $17-18, \%$} \\
\hline 23 & 33 & 34 & 10 \\
\hline \multicolumn{4}{|c|}{ Age of $19-20, \%$} \\
\hline 15 & 25 & 48 & 12 \\
\hline
\end{tabular}

The study results show that boys use more borrowing than girls. The representatives of both genders at the age of 17-18 years in their speech use more Anglo-Americanisms than those who are older. Concerning the gender characteristics, $62 \%$ of young men aged 17 and 18 prefer borrowing to the original words, young women $-56 \%$. At the age of 19-20, the indicator decreases: $49 \%$ and $40 \%$ accordingly. Very few people use the Ukrainian words (5-10\%). The number of older respondents is a little higher: the boys use $10 \%$ of the Anglo-Americanisms, the girls $-12 \%$. Young people who have a secondary education know fewer AngloAmericanisms, but they also use the loanwords. Only $13 \%$ of respondents believe that foreign words contaminate the Ukrainian language.

The people who use the loanwords seldom consider them to be the part of the Ukrainian lexical system that cannot replace the Ukrainian words. Thus, the results show that the study of foreign language entails a frequent use of the loanwords. Students studied English at school and continue to study at the university. The development of international exchange programmes also affects the speech style of students. The use of Anglo-Americanisms became a la mode for the Ukrainian youth caused by the rejection of generally accepted norms and traditions, paying increasing attention to the new, popular facts of reality. The students react quickly to changes in speech and put them into use. Most of all they borrow from many sources such as the Internet, TV and communication with other students.

The use of Anglo-Americanisms by the students and graduates of the colleges and technical schools.

According to the students of the colleges and technical schools, we can say that the results are different. The young people who are the students and graduates of colleges and technical schools know the meanings of Anglo-Americanisms well (Table 4). 
Table 4. The number of people who know the meaning of Anglo-Americanisms

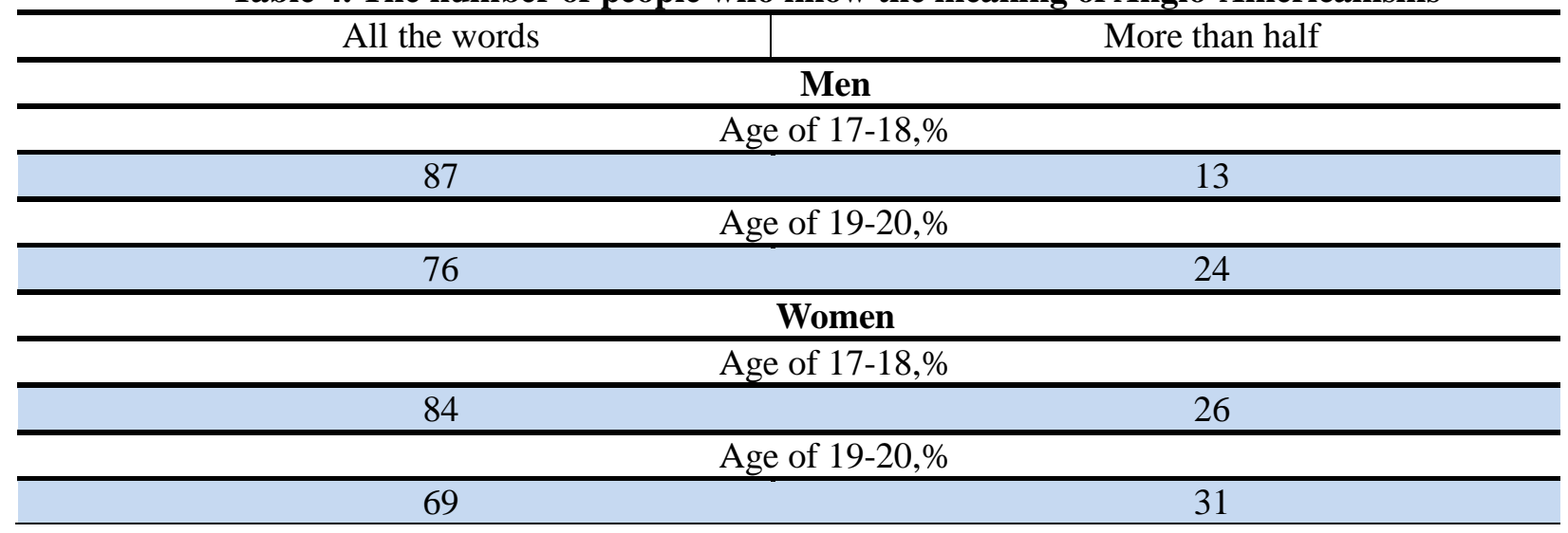

This group of students was also asked how often they use Anglo-Americanisms instead of Ukrainian words. At the age of 17-18, the difference between the groups is not considerable, about 1-3\%. Young people aged 19-20 use Anglo-Americanisms less often (Table 5).

Table 5. The number of people who use Anglo-Americanisms instead of the Ukrainian equivalents

\begin{tabular}{|c|c|c|c|}
\hline Always & Often & Seldom & Never \\
\hline \multicolumn{4}{|c|}{ Men } \\
\hline \multicolumn{4}{|c|}{ Age of $17-18, \%$} \\
\hline 25 & 27 & 35 & 13 \\
\hline \multicolumn{4}{|c|}{ Age of $19-20, \%$} \\
\hline 17 & 25 & 33 & 25 \\
\hline \multicolumn{4}{|c|}{ Women } \\
\hline \multicolumn{4}{|c|}{ Age of $17-18, \%$} \\
\hline 20 & 27 & 69 & 22 \\
\hline \multicolumn{4}{|c|}{ Age of $19-20, \%$} \\
\hline 14 & 15 & 40 & 31 \\
\hline
\end{tabular}

The young people of the second group use more Ukrainian words. At the age of $17-18,52 \%$ of boys and 47\% of girls prefer Anglo-Americanisms. The older adolescents use them less frequent: $42 \%$ and $29 \%$ accordingly. Approximately $45 \%$ of the respondents who use the loanwords perceive Anglo-Americanisms as their friendly words, and only $55 \%$ - as foreign ones. The respondents of this group use the Ukrainian words more often: $13 \%$ and $25 \%$ for the young men, $25 \%$ and $31 \%$ for the young women. Most respondents prefer to use Anglo-Americanisms rarely, only speaking to their friends.

The main reasons for the use of Anglo-Americanisms in their speech are the following: to be trendy $50 \%$ (i.e. to use the language which is incomprehensible to others $-40 \%$, it is fashionable $-40 \%$, it sounds unusual $-20 \%$ ), to enrich Ukrainian with new words $-20 \%$, to understand and be understood by friends $30 \%$. Thus, with the help of borrowed English words, one can pass on information to each other so that the teachers around you, parents or the uninitiated do not understand what is being said; English loans are often used on radio and television; English words sound very unusual. Only 18\% of respondents of this group believe that foreign words contaminate the Ukrainian language.

The types of Anglo-Americanism in the youth slang

The loanwords have derivatives in youth slang. Among the analysed words the following AngloAmericanisms were registered:

1) according to the names of diminutive-caressing words:

бейбі (baby) - бейбік, кеш (cash) - кешка, мані (money) - маніки /манічки, меседж (message) меседжик, респект (respect) - респектик, сюрпрайз (surprise) - сюрпрайзик;

2) the formation of verbs from nouns:

дрінк - дрінкати (to drink), кіс - кіситись (to kiss), френд - френдитися (to be friends), юзер юзати (to use);

3) the formation of adjectives from nouns:

кеш (cash) - кешовий, френд (friend) - френдовий, сюрпрайз (surprise) - сюрпрайзний. 
The Anglo-Americanisms are considered as a subsystem of the language social dialect, as evidenced by the presence of variants of rejection on models of specific words, for example:

друг (friend) - друзі (friends), френд (friend) - френди (friends);

хлопець (bоy) - хлопия, бой (boy)- боя;

дівчина (girl) - дівчини, герла (girl) - герли;

людина (person) - люди (people), піпл (people) - піпли (people).

The evidence indicates that the group of people who are getting higher education uses more English loanwords than the young people who are studying at technical schools. It can be explained by the fact that they continue to study English at the universities or institutes. However, the difference is not very large. Regarding gender indicators, it can be argued that boys use more Anglo-Americanisms than girls, which is associated with the characteristics of gender communication. Adolescents aged 17-19 use more English borrowing in their speech, but in general, the figures are not very different, which suggests that AngloAmericanisms have taken a strong position in the speech of youth slang.

\section{Discussions}

The study results demonstrate that the loanwords are used in the speech of all young people, regardless of their speciality and gender, as evidenced by the questionnaires of the subjects. The hypothesis of the research that claims the use of Anglo-Americanisms depending on age, gender and educational dimensions is partly approved. The difference between two groups is not significant. The unexpected results of the study have shown that there is no need to speak about differences between women's and men's speech at the age of 17-19 identifying distinct female and male language forms. The reason why young people prefer to use English words in their speech is the following: the use of English words is fashionable and is promoted by the media, English words sound unusually and give their speech a certain mystery.

Gender has a certain influence on the degree of the use of Anglo-Americanisms in the speech of youth: young men use English loans more often than young women. Thus, the degree of assimilation of borrowed Anglo-Americanisms in the speech of young people is quite high, which has been clarified in the course of our sociolinguistic experiment.

There is a trend to mixing languages in some strata of the language and that the growth and penetration of foreign structures into the language threatens destroying spoken language with the gradual loss of its specifics. The number of Anglo-Americanisms in the everyday-spoken style of the language and, consequently, in the youth slang, is only a result of the inevitable growth and development of world economic relations, and, accordingly, Anglo-American loans influence many cultures of the world. Processes of globalisation are the processes of spreading bilingualism, when people speak the native language and English.

Many loanwords are not necessary, because in the Ukrainian language there exist synonyms, analogues, and sometimes even one-word equivalents. The penetration of loans into the Ukrainian language in these cases is associated with the desire to use them as elements of a language game or as symbols of foreignness.

Further investigations of the Ukrainian lexical system will be connected with the different language levels. Linguists should pay attention to the young slang in order to determine the tendency of the Ukrainian language to change the lexical system and the degree of internationalisation of English in the world.

\section{Conclusions}

The young people who are the students of colleges and technical schools use the loans in different ways. It can be explained by the fact that the first group of the respondents study English more and thus they know it better. Most of the foreign loans that fall into youth slang are the subject to the rules of word formation, characteristic of the Ukrainian language.

The results of the study confirm the fact of globalisation of the English language and its influence on other languages. The study first provided the main aspects of the use of English equivalents instead of the Ukrainian words, taking into account age, gender and educational features of the youth on the basis of the sociolinguistic experiment, which has not been analysed in previous works. This study is the initial stage in the research of the problem of globalisation of the Ukrainian language, connected with the European integration processes of the Ukrainian society.

Under the influence of linguistic and extralinguistic factors, foreign loanwords can go beyond the scope of youth slang and become common, or they can disappear as obsolete or irrelevant forms. Everything depends on the educational goals of modern society. According to the educational trends and European orientation of the Ukrainian society, we can assume that globalisation processes in the Ukrainian language will continue. 
Considerable attention in the Ukrainian youth slang has been given to the use of the English words because of the development of the language contacts and English internationalisation in the world. Gender, age and educational indicators affect the use of English borrowings in the Ukrainian language, but these are not particularly different, which identify that Ukrainian youth slang is full of Anglo-Americanisms and this process is getting more intense. Adolescents use more loanwords, which are associated with a widespread use of social networks, but boys also replace the Ukrainian words with the English ones more often than girls. However, the difference is not significant. Young people who study at universities use more AngloAmericanisms in their speech, which is due to education innovations. The number of respondents who do not use borrowings is smaller. This suggests a tendency to replace the Ukrainian words with English, even if they have a full analogue. Linguists should pay attention to this fact in order to determine the dynamics of the Ukrainian language to change the lexical system and the degree of internationalisation of English in the world.

\section{References:}

Azhniuk, B. (2008). Anhlizmy u suchasnij ukrayins'kij, rosijs'kij ta ches'kij movakh [Anglisms in the modern Ukrainian and Czech languages]. Movoznavstvo, 2 (3), 191-197. Retrieved 10.08.19 from https://movoznavstvo.org.ua/vsi-nomera-zhurnalu/762008-2-3-berezen-cherven/516-azhnyuk-b-m-anglizmi-v-suchasnij-ukrajinskij-rosijskij-i-cheskij-movakh.html

Chaoyuan, L. (2016). Review on language studies \& globalisation. Intercultural communication studies, XXV(3), 320-326. Retrieved 10.08.19 from https://web.uri.edu/iaics/files/LI-Chaoyuan.pdf

Cheshire, J. (2002) Sex and gender in variationist research. In J.K.Chambers, Peter Trudgill and Natalie Schilling-Estes (eds.), Handbook of Language Variation and Change (pp. 423-443). Oxford: Blackwell.

Fairclough, N. (2007). Strategy and discourse in globalisation and development. Gloabalization and policies of development. Bucharest: National School of Political Science and Public Administration.

Hans, V. B. (June 20, 2017). Globalisation: Changing language and landscape in hybrid times. International Journal of English Language, Literature, 7(3). Available at SSRN https://ssrn.com/abstract=2989413

Hjarvard, S. (2003). The globalisation of language. How the media contribute to the spread of English and the emergence of medialects. Media, globalisation and identity, III, 75-97. Retrieved 10.08.19 from https://pdfs.semanticscholar.org/ 0d77/16c3b1d26252da52729a987fc57ee61660ef.pdf

Kiramba, L. K. (2018). Language ideologies and epistemic exclusion. Language and education, 4(32), 291-312. https://doi.org/10.1080/09500782.2018.1438469

Leleka, T. \& Moskalenko, O. (2018). Psycholinguistic Peculiarities of the Assimilation of Anglo-Americanisms by the Speakers of Ukrainian-English Bilingualism. Psycholinguistics, 24(2), 144-162. https://doi.org/10.31470/2309-1797-2018-24-2-144-162

Ross, M. D. (2003). Diagnostic prehistoric language contacts. Motives for language change. Cambridge: CUP.

Sender, D. (2015). Language, multiple authenticities and social media: The online language practices of university students in Mongolia. Journal of sociolinguistics, 19 (4), 437-459. https://doi.org/10.1111/josl.12134

Sunderland, J.\& Swann, J. (2015).Teaching language and gender. LLAS Centre for languages, linguistics and area studies (20112016). Retrieved 10.03.18 from https://www.llas.ac.uk/resources/gpg/2827.html

Vasylenko, Yu.M. (2001). Molodizhnyi sleng [Youth slang]. Bulletin of Ivan Franko Lviv State University. Journalism, 21, $501-506$. 